\title{
Erratum: mRNA and Protein Expression of Selective Alpha Subunits of G Proteins are Abnormal in Prefrontal Cortex of Suicide Victims
}

In an article in the October issue [Dwivedi $Y$, Rizavi HS, Conley RR, Roberts RC, Tamminga CA, Pandey GN (2002): mRNA and Protein Expression of Selective Alpha Subunits of G Proteins are Abnormal in Prefrontal Cortex of Suicide Victims. Neuropsychopharmacology
27(4): 499-517], incorrect information was printed in Table 1 on pages 504. The correct information is as follows: All control subjects had a Psychiatric Diagnosis of "No psychiatric illness." 